\title{
Fruit susceptibility of several cultivars of blueberry (Vaccinium corymbosum L.) to diseases
}

\section{Podatność owoców kilkunastu odmian borówki wysokiej (Vaccinium corymbosum L.) na choroby}

\author{
Jan Kućmierz, Jacek Nawrocki, Anna Sojka
}

\section{Summary}

The observations were conducted on 11 cultivars of blueberry at different time of fruit maturing (early ripening, about average time of maturing and late ripening) and at three dates: during fruit set, maturing of fruit and harvest time. Quite significant differences in the susceptibility of each cultivar in each group to fruit diseases, which also depended on the phase of their development, were revealed. Based on three evaluations of health status of blueberry plants it has been concluded that the most sensitive to diseases are cultivars: Blueray, Crotan, and Bluejay, and the most resistant: Boniface, Puru and Brigitta.

Key words: blueberry, cultivars, fruit diseases, susceptibility

\section{Streszczenie}

Obserwacje przeprowadzono na 11 odmianach borówki wysokiej o różnych porach dojrzewania (wcześnie dojrzewające, o średniej porze dojrzewania i późno dojrzewające), w trzech terminach: zawiązywanie owoców, dojrzewanie owoców i okres zbiorów. Wykazano dość znaczne zróżnicowanie w podatności poszczególnych grup odmian na choroby owoców, także w zależności od fazy ich rozwoju. Z trzech terminów przeprowadzonych obserwacji zdrowotności owoców wynika, że najbardziej wrażliwymi na choroby są odmiany: Blueray, Croatan i Bluejay, zaś najodporniejszymi: Bonifacy, Puru i Brigitta.

Słowa kluczowe: borówka wysoka, odmiany, choroby owoców, podatność

Uniwersytet Rolniczy im. Hugona Kołłątaja w Krakowie

Katedra Ochrony Roślin

Al. 29 Listopada 54, 31-425 Kraków

j.nawrocki@ogr.ur.krakow.pl 


\section{Wstęp / Introduction}

Wysoka wartość odżywcza, smakowa i zdrowotna owoców borówki wysokiej sprawia, że w ostatnich latach wzrasta areał jej uprawy (Nowiński 1977; Smolarz 2008). Mimo, że nadal główną przyczyną większości chorób Vaccinium corymbosum L., wpływających na wysokość i jakość plonu owoców są czynniki nieinfekcyjne, to wzrasta szkodliwość chorób infekcyjnych (powodowanych przez wirusy, bakterie, organizmy grzybopodobne i grzyby) oraz szkodników (Pliszka i wsp. 2002; Szmagara 2005; Łabanowska 2010). Znacznie lepsze rozeznanie w literaturze dotyczy patogenów atakujących liście i pędy (Borecki i Pliszka 1979; Zalewska 1999; MachowiczStefaniak i Zalewska 2001; Szmagara 2005; Szmagara i wsp. 2006; Bryk 2010), natomiast niewiele danych opisuje choroby owoców borówki wysokiej (Zalewska i wsp. 2007) - stąd zainteresowanie tym problemem, tym bardziej, że z terenu Małopolski jest coraz więcej doniesień o chorobach owoców i przedwczesnym opadaniu zawiązków owocowych.

\section{Materiały i metody / Materials and methods}

Badania wykonano w latach 2008 i 2009 na prywatnej plantacji borówki wysokiej o powierzchni 1 ha, w okolicach Krakowa. Plantacja zlokalizowana jest na wzniesieniu, w pobliżu lasu mieszanego, w międzyrzędziach utrzymywana jest murawa lub naturalne zadarnienie, a w rzędach użyto trocin do ściółkowania gleby. $\mathrm{Na}$ plantacji nie były stosowane żadne środki do zwalczania chorób i szkodników. Plantacja była obsadzona następującymi odmianami: Bluetta i Sunrise o wczesnej porze dojrzewania, Bluejay, Blueray, Bluecrop, Bonifacy, Croatan i Puru o średniej porze dojrzewania oraz Brigitta, Garrow i Jersey o późnej porze dojrzewania.
Do ścisłych obserwacji wytypowano losowo po 2 krzewy z każdej odmiany. Ocenę zdrowotności zawiązków owocowych i owoców przeprowadzano bezpośrednio na plantacji w trzech terminach: w czasie opadania kwiatów i tworzenia zawiązków owocowych (trzecia dekada maja), w czasie rozpoczęcia dojrzewania owoców (pierwsza dekada lipca) i pełnej dojrzałości owoców (pierwsza dekada sierpnia). W trakcie każdej obserwacji, na każdym krzewie badano po 100 losowo wybranych zawiązków lub owoców i określano procentowy udział owoców i zawiązków owocowych z objawami chorobowymi. Materiał ten służył do dalszych badań makroi mikroskopowych $\mathrm{w}$ laboratorium. Wyniki z obu lat były bardzo zbliżone, dlatego na wykresach podano średnie z obu lat obserwacji (rys. 1, 2).

\section{Wyniki i dyskusja / Results and discussion}

Na podstawie przeprowadzonych obserwacji stwierdzono, że zawiązki owocowe i owoce wszystkich 11 przebadanych odmian są wrażliwe na choroby. Wykazano jednak dość znaczne zróżnicowanie ich podatności w zależności od odmiany, terminu obserwacji oraz pory ich dojrzewania (rys. 1, 2).

Z odmian wcześnie dojrzewających bardziej odporna na infekcje patogenów zawiązków owocowych i owoców okazała się odmiana Bluetta $(4,4 \%)$ od odmiany Sunrise $(5,1 \%)$. Wśród odmian o średnim okresie dojrzewania owoców, najwrażliwszymi odmianami okazały się Blueray $(7,1 \%)$ i Croatan $(6,4 \%)$. Z odmian o późnym okresie dojrzewania owoców, najwięcej chorych zawiązków owocowych i owoców stwierdzono na odmianie Darrow $(4,9 \%)$ (rys. 1$)$. Biorąc pod uwagę terminy przeprowadzonych obserwacji nad chorobami zawiązków owocowych i owoców wykazano, że w okresie zawiązywania owoców

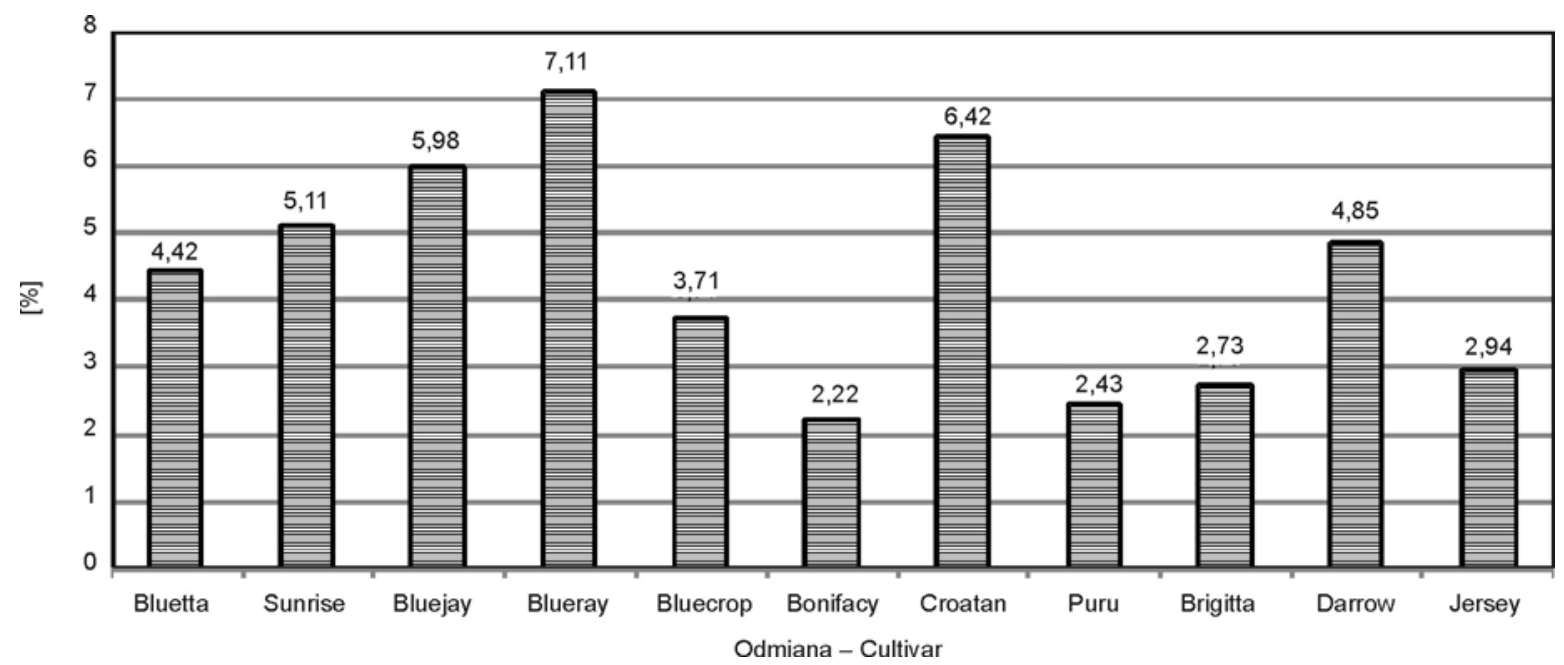

Rys. 1. Procent zawiązków owocowych i owoców z objawami chorobowymi u badanych odmian borówki wysokiej (średnio dla lat 2008 i 2009)

Fig. 1. The percentage of fruit germs and fruits with symptoms of disease in the tested cultivars of blueberry (average for years 2008 and 2009) 


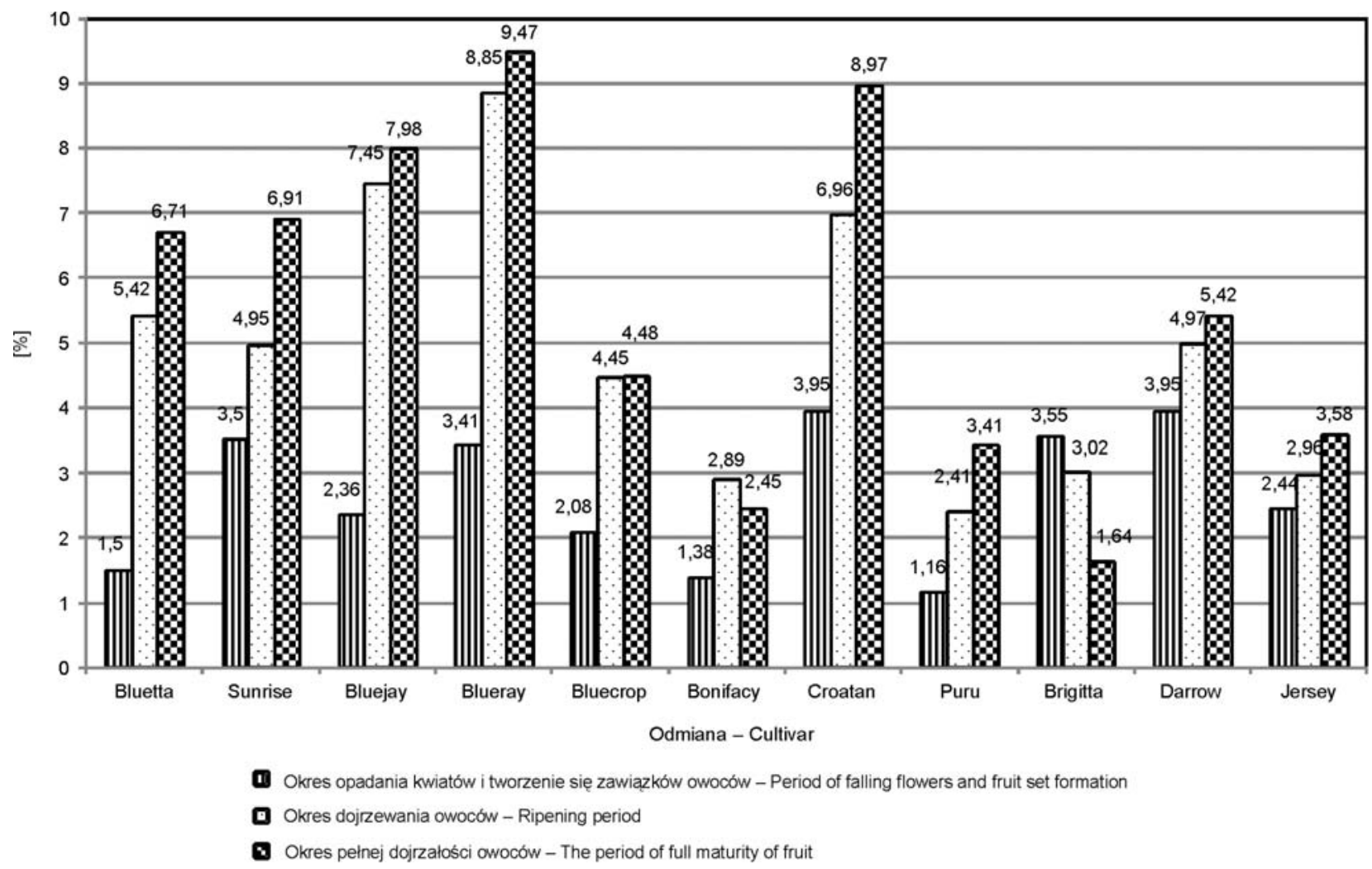

Rys. 2. Procent zawiązków owocowych i owoców z objawami chorobowymi w zależności od odmiany borówki wysokiej i terminu prowadzonych obserwacji (średnio dla lat 2008 i 2009)

Fig. 2. The percentage of fruit germs and fruits with symptoms of disease depending on the blueberry cultivar and timing of observations (average for years 2008 and 2009)

ogólnie odnotowano $2,75 \%$ zawiązków z objawami chorobowymi, przy czym najwięcej na odmianach: Darrow i Croatan $(4,0 \%)$, a najmniej na odmianach: Bluetta $(1,5 \%)$, Bonifacy $(1,4 \%)$ i Puru $(1,2 \%)$. W okresie dojrzewania owoców średni procent owoców z objawami chorobowymi dla wszystkich odmian wynosił 4,4\%. Najwięcej takich owoców stwierdzono na odmianach: Blueray $(8,9 \%)$ i Bluejay $(7,5 \%)$, a najmniej na odmianach: Puru $(2,4 \%)$ oraz Bonifacy $(2,9 \%)$ i Jersey $(3,0 \%)$. Najwięcej chorych owoców zaobserwowano w okresie ich pełnej dojrzałości, kiedy to średnia dla wszystkich 11 odmian wynosiła 5,6\%, w tym najwięcej na odmianach: Blueray $(9,5 \%)$ i Croatan $(9,0 \%)$, a najmniej na odmianach: Brigitta $(1,6 \%)$ i Bonifacy $(2,5 \%)$ (rys. 2). Ten najwyższy procent owoców $\mathrm{z}$ objawami chorobowymi $\mathrm{z}$ ostatniego terminu obserwacji sugeruje, że przyczyną wzrostu liczby owoców chorych moga być warunki atmosferyczne, np. duże opady deszczu lub gradu oraz szkodniki, w tym ptaki, na co zwrócili uwagę Szmagara i wsp. (2006). Dość znaczny udział chorych zawiązków owocowych sugeruje, że infekcja grzybami patogenicznymi nastapiła $\mathrm{w}$ okresie kwitnienia roślin.

Uwzględniając wszystkie trzy terminy obserwacji zdrowotności zawiązków owocowych i owoców można wskazać, że najbardziej wrażliwymi na patogeny są odmiany: Blueray $(7,1 \%)$, Croatan $(6,4 \%)$ i Bluejay $(6,0 \%)$, zaś najodporniejszymi są odmiany: Bonifacy $(2,2 \%)$, Puru $(2,4 \%)$, Brigitta $(2,7 \%)$ (rys. 1$)$.

\section{Wnioski / Conclusions}

1. Wśród przebadanych 11 odmian borówki wysokiej stwierdzono dość znaczne zróżnicowanie w ich podatności na choroby zawiązków owocowych i owoców.

2. Procent zawiązków owocowych i owoców z objawami chorobowymi zależał od terminu przeprowadzonych ocen oraz grupy odmian o określonej porze dojrzewania owoców.

\section{Literatura / References}

Borecki Z., Pliszka K. 1978. Zgorzel pędów borówki wysokiej wywołana przez grzyb Gordonia cassandre (Pedic.) Groves. Acta Agrobot. 30 (1/2): 159-171. 
Bryk H. 2010. Choroby występujące na plantacjach borówki wysokiej. s. 54-58. W: Materiały Ogólnopolskiej Konferencji Nauka Praktyce „Intensyfikacja uprawy krzewów jagodowych przez wdrażanie najnowszych wyników badań”. ISiK, Skierniewice, 20-21 kwietnia 2010, 97 ss.

Łabanowska B. 2010. Szkodniki borówki wysokiej i możliwości ich zwalczania. s. 59-64. W: Materiały Ogólnopolskiej Konferencji Nauka Praktyce „Intensyfikacja uprawy krzewów jagodowych przez wdrażanie najnowszych wyników badań. ISiK, Skierniewice, 20-21 kwietnia 2010, 97 ss.

Machowicz-Stefaniak Z., Zalewska E. 2001.Grzyby zasiedlające nadziemne organy borówki wysokiej - Vaccinum corymbosum L. s. 213-215. W: Materiały Ogólnopolskiej Naukowej Konferencji Ochrony Roślin Sadowniczych. ISiK, Skierniewice, 22-23 luty 2001, 259 ss.

Nowiński M. 1977. Dzieje roślin i upraw ogrodniczych. PWRiL, Warszawa, 367 ss.

Pliszka K., Cichocka F., Dzięcioł R., Karwowski L., Marzec-Wołoszczyńska T., Ścibisz K., Żakowicz S. 2002. Borówka wysoka. PWRiL, Warszawa, 152 ss.

Smolarz K. 2008. Borówka wysoka. Wyd. Działkowiec, Warszawa, 72 ss.

Szmagara M. 2005. Występowanie i etiologia chorób pędów borówki wysokiej (Vaccinium corymbosum L.) uprawianej w południowowschodniej Polsce. Praca doktorska, AR Lublin, 80 ss.

Szmagara M., Zalewska E., Machowicz-Stefaniak Z. 2006. Choroby występujące na nadziemnych organach borówki wysokiej (Vaccinium corymbosum L.). s. 86-92. W: Materiały Międzynarodowej Konferencji Naukowej „Uprawa borówki i żurawiny”. ISiK, Skierniewice, 19-22 czerwca 2006, 262 ss.

Zalewska E. 1999. Monilia spp. the pathogens of fruit plants. Ann. Univ. Maria Cure-Skłodowska, Lublin, Sectio EEE, 7: $137-144$.

Zalewska E., Król E., Machowicz-Stefaniak Z. 2007. Grzyby zasiedlające owoce borówki wysokiej (Vaccinium corymbosum L.) uprawianej w południowo-wschodniej Polsce. [Fungi colonizing the fruits of blueberry (Vaccinium corymbosum L.) cultivated in south-eastern Poland]. Prog. Plant Prot./Post. Ochr. Roślin 47 (2): 380-384. 